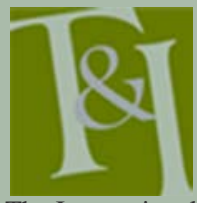

The International Journal for Translation \& Interpreting Research trans-int.org

\title{
Rethinking the interpreter's agency in wartime: a portrait of Gottlieb Fuchs
}

\author{
Lucía Ruiz Rosendo \\ University of Geneva \\ Lucia.Ruiz@unige.ch
}

DOI: 10.12807/ti.111202.2019.a06

\begin{abstract}
This article explores the interpreter's agency in wartime. It presents a case study of Gottlieb Fuchs, a Swiss citizen who worked as the interpreter for Klaus Barbie, the Gestapo commander of German-occupied Lyon, during the Second World War. The study focuses on the analysis of his memoirs as a personal narrative and some letters written by former Gestapo prisoners and camp inmates. Gottlieb Fuchs's story is an unusual one: working as a triple agent from 1942 to 1944 in the context of the Second World War, Fuchs collaborated simultaneously with the Germans, the French Resistance and the government of his native Switzerland. Despite their official neutrality in the war, the Swiss used Fuchs as a source of information with which to help prepare for a mobilisation if faced with a German invasion. Driven by solid ideological values, Fuchs used his position to protect political prisoners, and played, therefore, a humanitarian role during the German occupation of France. I focus on this particular case study in order to analyse the role of emotions and ideology in the interpreter's agency in contemporary wars. I argue that emotions have an important impact on the interpreter's agency in extreme conditions. I also posit that the interpreter may not always be aware of the direct or indirect implications of using or misusing his complex positionality to attain certain goals, and that there are unforeseen repercussions that stem from the interpreter's decisions and are beyond his control.
\end{abstract}

Keywords: interpreting, habitus, emotions, ideology, Gottlieb Fuchs, Klaus Barbie.

\section{Introduction}

“All of us have a secret wound we fight to redeem” (Calvino, 1964, p. 109).

Je me considérais comme à nouveau mobilisé au service de mon pays. Et il y avait aussi cette France hospitalière qui avait su accueillir avant la guerre des compatriotes sans emploi, poussés comme moi à émigrer avec leur famille. J'avais envers elle une dette de reconnaissance. (...) Le spectre du fascisme dans mon pays avait éveillé ma conscience politique (Fuchs, 1973, p. 29) ${ }^{1}$.

La guerre réveille le soldat qui dort. La réalité d'un enfer que l'homme tente d'instaurer sur cette terre et qu'il faut combattre de front au jour le jour chasse les terreurs de ces ténèbres imaginaires racontées aux petits enfants (Fuchs, 1973, p. $96)^{2}$.

\footnotetext{
${ }^{1}$ I considered myself once again to have been mobilised in service of my country. And there was also France, which, before the war, so welcomingly opened its doors to my unemployed fellow countrymen, forced like me to emigrate with their family. I owed them a debt of gratitude (...) The spectre of fascism in my country had awoken my political awareness. (All translations from French are provided by the author).

${ }^{2}$ War awakes the sleeping soldier. The reality of a hell that men are trying to establish on this earth and which must be fought head-on, day-in day-out, chases away even the horrors of that imaginary darkness in the tales we tell small children.
} 
The first quote from Italo Calvino is used by Costalli and Ruggeri (2015) to declare that ideas influence human behaviour in many circumstances, including those involving political action. The two reminiscences included in Théophile-Gottlieb Fuchs's memoirs, entitled "Le Renard". 30 ans après l'interprète de Barbie parle, illustrate his strong ideology and the emotions he felt starting to work as an interpreter for the Nazis under the German occupation of France, and seizing this opportunity to mobilise himself against them. Drawing upon Baker's (2006) theory of narrativity and Reay's (2015) psychosocial understanding of the Bourdesian notion of habitus, in this paper I explore the impact of ideology and emotions on the interpreter's agency in contemporary wartime through the analysis of an ontological narrative, allowing us to reconstruct lived experiences and historical context. This analysis shows how the decisions taken by an interpreter working for the Gestapo during the German occupation of France were filtered through, if not at times entirely defined by, his ideology and emotions. In addition, it reveals how the affective (or the underlying emotional state) played an important role in shaping his habitus. Gottlieb Fuchs was a Swiss interpreter who worked as a triple agent for the Germans, the French Resistance and the Swiss government from 1942 to 1944 in the context of the Second World War. The unusual relationship which formed between Fuchs and Gestapo officer Klaus Barbie ${ }^{3}$ provides an excellent opportunity to delve into the implications of the interpreter's agency and consider the unforeseen repercussions that stemmed from Fuchs's active role and (un)conscious decisions, and over which he had no control.

Fuchs describes his experience working with and for the Gestapo, with a closer look at his view of Barbie, his collaboration with the French Resistance and, to a lesser extent, with the Swiss government. The relationship created between Fuchs and Barbie, the view that Fuchs had of Barbie as an unintelligent, temperamental and irascible man and his view of the tasks he had to perform provide a basis for determining the extent to which the decisions taken by Fuchs were filtered through, nullified or defined by his personal experiences. Fuchs's decisions were influenced by considerations of what was morally acceptable or not, and by a conception of what was right or wrong. The examination of his experiences suggests that, in wartime, the interpreter's agency is a complex notion. The study of ideology and emotions, inextricably linked to temporal and spatial considerations, should be taken into account to enrich our understanding of the interpreter's agency in wartime.

\section{The role of the affective in Bourdieu's habitus}

A useful notion with which to examine the interpreter's agency is Bourdieu's notion of habitus. In recent decades, some authors have applied Bourdieu's sociological framework to interpreting and the role of interpreters (Delgado \& Kherbiche, 2018; Guo, 2015; Inghilleri, 2005a, 2005b). These authors rightly highlight the relevance of this theory to translation and interpreting contexts,

\footnotetext{
${ }^{3}$ Klaus Barbie, also known as "the butcher of Lyon", was the head of section IV of the Lyon Einsatzkommando SIPO-SD (German Security Police) during the German occupation of France. He was charged with identifying Nazi enemies and was responsible for "Jewish affairs" and the fight against the French Resistance. He was responsible for the torture and deportation of thousands of Jews and members of the Resistance during 1942 to 1944. He disappeared after the war but, many years later, it became known that, from 1947 to 1951, he had been recruited as an informer - given his experience in intelligence and his anti-communist fervour (Rousso, n.d.) for the US CIC (Counterintelligence Corps) (see Suleiman, 2002). He then escaped to South America, where he adopted the name of Klaus Altmann and took refuge in Bolivia. Only in February 1983, after the installation of a democratic regime in Bolivia, was he taken to France, convicted of crimes against humanity and incarcerated in Lyon. His trial was a watershed in French history because it established a new definition of crimes against humanity in French law.
} 
particularly of the notions of habitus, field and capital ${ }^{4}$, and how these notions influence the interpreter's agency, defined by Inguilleri (2005b, p. 76) as "how interpreters position themselves and are positioned within interpreting contexts”.

I argue that, in order to understand the interpreter's habitus and agency in a war scenario, which is characterised by uncommon and extreme conditions, it is important to go beyond the consideration of objective and tangible factors to encompass the notion of the affective. Along these lines, I agree with Reay (2015) that the concept of habitus does not engage sufficiently with the domain of the affective. This author develops Bourdieu's theory to include the emotional aspects of lived experience, focusing on the concept of habitus and its relationship with the concept of field. She posits that Bourdieu actually refers to internal conflicts and powerful emotions when there is a lack of integration of the disparate experiences of an individual: “... implicit within notions of the divided habitus are ambivalence, compromise, competing loyalties, ambiguity and conflict” (Reay, 2015, p. 11). In her psychosocial understanding of habitus, Reay emphasises Bourdieu's reference to the affective and the constitution of the habitus of bodily beliefs that are emotions, arguing that the confrontation between the habitus and the field is always marked by affectivity, by affective transactions between habitus and the field (see Reay, 2004, for an in-depth interpretation of the concept of habitus):

We are disposed because we are exposed. It is because the body is (to unequal degrees) exposed and endangered in the world, faced with the risk of emotion, lesion, suffering, sometimes death, and therefore obliged to take the world seriously (and nothing is more serious than emotion, which touches the depth of our organic being) that it is able to acquire dispositions that are themselves an openness to the world, that is, to the very structures of the world of which they are the incorporated form. (Bourdieu, 2000, pp. 140-141)

In Reay's analysis, there is a relationship between inner emotional worlds and external social and structural processes that are enabled by the notion of habitus and that enrich this very notion.

Although Reay's approach focuses on educational research, I argue it can be adapted to interpreting studies research, particularly to the field of interpreting in war zones. In war situations, the interpreter, as an individual who is embedded in the conflict, is confronted with extreme situations and exposed to strong narratives that justify the existence of opposite ideologies, triggering different emotions. These emotions become sedimented in the interpreter's habitus and have an impact on the position he adopts as an active agent who has a visible individual identity and affects other parties' stakes. Although in the last decade there has been a productive debate about the analysis of the interpreter's agency through the notion of habitus, the role of the affective in the habitus and how it influences the interpreter's agency in wartime still merits a more in-depth examination.

\footnotetext{
${ }^{4}$ The concept of habitus refers to the durable dispositions - from which is built a structure that integrates all past experiences - that constitute the basis of the agents' perception of the state of the situation in specific social conditions and that consequently guide the agents' strategies for expression. These dispositions function as a matrix of perceptions, appreciations and actions. This concept is related to the concept of field, the latter being defined as a distinct sub-space within the global space, as a "relatively autonomous domain of activity that responds to rules of functioning and institutions that are specific to it and which define the relations among the agents" (Hilgers \& Mangez, 2014, p. 5). The habitus structures the field and "contributes to constituting the field as a meaningful world" (Wacquant, 1989, p. 44). If we apply these concepts to the interpretative context, we could argue that the interpreter is embedded in a given field and that the relationship between this field and his habitus conditions his position.
} 


\section{Emotions and ideology in wartime}

Emotions permeate social life and play an important role in conflicts. In their study on the impact of emotions on responses given in different contexts, Sabucedo, Durán, Alzate \& Barreto (2010) define emotions as "reactions to cognitive evaluations of an individual's environment” (p. 28). Rosler, CohenChen and Halperin (2017), in their appraisal theories of emotions, underline the importance of group-based emotions: emotions felt by individuals as a result of their being members of a group against an out-group considered as a homogeneous entity which fuel the underlying psychological mechanism in conflict escalation and de-escalation. And Halperin (2011, p. 23) defines "emotions" as "flexible response sequences that transform a substantive event into a motivation to respond to it in a particular manner". If we apply these definitions to interpreting in wartime, emotions could be defined as reactions that involve conscious and unconscious cognitive appraisals affected by previous beliefs and events, the unique framing of an event, the ideology about the conflict and the pre-existing emotional sentiments about the opponent, which influence the interpreter's position and his response to a certain event.

Emotions are very often associated with ideology in wartime. Ideologies, including both preferences and beliefs, constitute an intrinsic part of groups who adopt them instrumentally. These groups invest a significant amount of time into producing and communicating ideas which identify a certain constituency and the associated objectives and challenges, and determine the actions and strategies to be taken by the group, institutions, as well as the friends and foes of this group. In this paper I adopt the definition proposed by Gutiérrez Sanín and Wood (2014, p. 215):

A more or less systematic set of ideas that includes the identification of a referent group (a class, ethnic, or other social group), an enunciation of the grievances or challenges that the group confronts, the identification of objectives on behalf of that group (political change - or defence against its threat), and a (perhaps vaguely defined) program of action

Given the intangible, volatile and abstract nature of ideologies, they are transmitted through narratives that are developed by the different parties in wartime. These narratives come to be owned and adopted by the individuals immersed in the conflict, and this leads them to feel and behave in a certain fashion. In extreme cases, belonging to an ideology leads the individual to develop negative emotions towards outsiders, such as anger or hatred, but also resentment or indignation. Similarly, positive emotions grow towards the insiders, such as empathy. From the moment that emotions influence how people assess the surrounding information and narratives, it also influences cognition and action (Pearlman, 2013).

Analysis of Fuchs's memoirs shows how he had adopted an ideology that had triggered opposite feelings of, on the one hand, hatred, indignation and resentment towards the German forces and, on the other, of allegiance towards the members of the Resistance and of compassion towards the victims of the occupying forces. In order to understand how these emotions influenced his habitus and agency, it is important to first of all understand the context in which he worked as an interpreter.

\section{A case study of an interpreter and double agent}

Under the German occupation of France, interpreters were needed to communicate with the local populations and authorities. These interpreters, with their knowledge of French and German, often played an important role in 
assisting the occupying forces in their political dominance and military control. Given the clash between the occupiers and the French members of the Resistance, and between the latter and the French "collaborationists", and the violence and oppression by the German forces, interpreters working for the Germans had a complex positionality that stemmed from their own views of the conflict. As Ott (2009, p. 65) explains in her study on Franco-German relations, interpreters "were not always sympathetic to the German cause".

Gottlieb Fuchs, from German-speaking Switzerland, worked as interpreter to Gestapo officer Klaus Barbie between 1942 and 1944. Unlike other interpreters who were recruited by force or circumstance, Fuchs chose to interpret for the Germans. He was called "le Renard", the French translation of his surname ("fox") and was known to the Germans by the pseudonym "Doktor Edouard Rochat", a French name Fuchs chose in order to be more easily accepted by the members of the Resistance. He had migrated to France in 1936 due to the employment crisis in Switzerland and was in Toulouse when the 1940 armistice was signed (see Germain, 1992).

Fuchs always showed his desire to help his compatriots defend their interests - he even created the Innerschweizerischen Auswandererverein [Association of Immigrants of Central Switzerland] - and developed an activist spirit very early on. In 1942 he successfully answered a job offer in the newspaper Dépêche de Toulouse and started to work as an interpreter for the German Red Cross at the French demarcation line ${ }^{5}$. He decided to infiltrate the German organisation in order to gather intelligence for his country and for France, and received permission to establish close relations with the Germans to gather intelligence for the Swiss government. In October 1942, while employed as an interpreter at Dijon train station, he met young officer Klaus Barbie and was recruited as his interpreter because he spoke French and knew people in the area close to the Swiss border, the Pays de Gex. (This reflects the widespread view that linguistic skills are the same as interpreting skills). He did not only interpret but also translated official documents, and with time became Barbie's confidant. While assisting Barbie he had the opportunity to meet German Nazi officers and important members of the Resistance, and he managed to gain the respect and trust of both. His official work as an interpreter also allowed him to gather information on the movements of German troops near the Swiss border.

He then worked in the Gestapo's headquarters in Lyon, the Hotel Terminus, as well as the École de santé militaire where he was promoted to the position of "interprète général " and became the "chef de la réception"”. Fuchs was also in charge of translating letters of denunciation sent to the Gestapo by informers, checking the letters that prisoners in Montluc prison sent to their families, and keeping an eye on items stored in the Gestapo headquarters that had been previously confiscated from the Jews. He continued to be an informant for the Swiss security services and for the French Resistance: he revealed the names of German agents who operated in Geneva and informed the French Resistance of the raids and arrests that were going to take place.

In the fall of 1943, Fuchs was sent to the Hotel Pax in Annemasse as an interpreter and substitute for the examining magistrate, where he continued to act as a double agent. At the end of 1943, Fuchs was uncovered after he was betrayed by a compatriot. He was tortured and sentenced to death but, at the last minute, the sentence was commuted to deportation. In 1944 he was deported to a concentration camp in Trèves, and then to the Dora-Mittelbau camp. A

\footnotetext{
${ }^{5}$ After France's defeat in 1940, German troops drew a demarcation line to separate the territory occupied and administered by the German regime (Northern and Western part of France) and the Free Zone (Southern part of France). This demarcation line was created following the Armistice of June 22, 1940.

${ }^{6}$ General interpreter.

${ }^{7}$ Chief receiving officer.
} 
German officer found out that he spoke German and he was led to the camp's kitchen to assist the chef.

After being reported by a Polish inmate for passing on food to the other inmates, Fuchs was brutally beaten and carried to the infirmary, where he was recruited by the doctor as a male nurse because he spoke German. He was then transferred to the camp of Bergen-Belsen, which was liberated by British troops shortly after his arrival. After the Liberation, the Swiss government sent him to prison in Switzerland for having collaborated with the Germans. He was also prosecuted for undertaking intelligence work for a foreign power with little regard for Swiss neutrality. This means that, contrary to other interpreters who also worked as double agents (see Guo, 2015), Fuchs's intelligence work was not greatly valued by the Swiss government after the Liberation, and in fact this was one of the major disappointments that Fuchs relates in his memoirs.

While working as an interpreter, and using his position as Barbie's righthand man, Fuchs actively supported the members of the Resistance: he acquired information that allowed him to prevent the arrests of members of the Resistance; when translating the letters of denunciation, he toned down the accusations and highlighted letters that were ridiculous ("voilà des minables qui croient que vous avez du temps à perdre" ") (Fuchs, p. 75); when required to buy food supplies, he paid an exorbitant amount to French farmers ("le prix du kilo de pommes de terre fiché par Vichy était de trois francs. Je l'achetai trente-cinq francs"”) (ibid., p. 77). He falsified Barbie's signature and secretly used the official seals to produce permits for agents of the Resistance to cross the border, and also falsified letters of release for French citizens who had received a summons. In Montluc prison he did not censor the letters sent by the prisoners to their families, and allowed parcels containing food or even files to enter. He even secreted medicines in parcels sent to help ill prisoners. In Annemasse, seizing the moments in which the examining magistrate was drunk, he helped to release the prisoners under arrest in the Pax prison by warning them and altering the information: "quand vous serez interrogé, vous me raconterez ce que vous voudrez en français et moi, je traduirai à ma manière : j’écrirai en

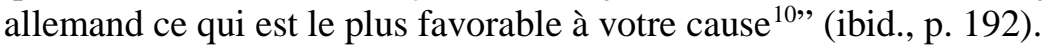

On other occasions, when he took the statements of women who had denounced their husbands as members of the Resistance, he did not systematically transmit the accusation to his superiors:

Je devais aussi écouter les confidences d'un tout autre genre de clients : des femmes de tous les milieux qui se déplaçaient pour dénoncer, sous des prétextes hypocrites, un mari gênant (...). Comme elles devaient passer par mon intermédiaire, l'affaire ne montait pas au-dessus (ibid., p. 119) ${ }^{11}$.

Fuchs was even consulted by Barbie on potential arrests, and his opinions had an influence on Barbie's decisions, as in the case of cardinal Gerlier who ultimately was not detained. Using the power afforded to him by speaking French - a language that the local Gestapo did not understand - he gave instructions to those about to be arrested, as in the case of a young man who had been denounced by a woman who apparently was pursuing him: "vous êtes

\footnotetext{
${ }^{8}$ These pathetic wretches think you have time to waste on them.

${ }^{9}$ Vichy had fixed the price for one kilogram of potatoes at three francs. I bought it for thirty-five francs.

${ }^{10}$ When you are interrogated you can tell me whatever you like in French and I will translate it in my own way: I will write down, in German, whatever is most favourable for your cause.

${ }^{11}$ I also had to hear testimony from quite another type of client: women from any and all walks of life who came, with hypocritical excuses, to inform on their irritating husbands (...). Since they had to go through me, the issue went no further.
} 
convoqué demain matin à 6 heures à la Gestapo. Et j'ajoutai : et j'espère que vous serez déjà loin ${ }^{12}$ " (ibid., p. 184).

While interned in the concentration camp, Fuchs decided to use his position to help the other inmates, choosing in this way the empathic side as found in the ambiguous pattern of servility-empathy and collaborationsolidarity put forward by Ashenberg (2016). Wolf (2016) illustrates the role of those interpreters who put their skills at the service of their fellow inmates in order to ease their living conditions, maintain their moral integrity and comfort them, as opposed to the role of interpreters who collaborated with the SS ${ }^{13}$. In Fuchs's case, one may argue that the decision to help others went back a long way, and that it was not an impulse, contrary to the cases analysed by Kuhiwczak (2016). The latter is based on Bauman's (1988) stance on the choice between moral duty and self-preservation: Bauman argues that the decision to help others is a direct expression of an individual's character and not a result of calculation.

The help that Fuchs provided to political prisoners is documented in several letters of acknowledgment, as in the case of doctor Jean Reverzy's attestation of the support he received from Fuchs while detained in the École de santé, declaring that Fuchs saved him from prison and deportation. In an environment in which terror reigned, Reverzy describes Fuchs as an empathetic and polite man who was outraged by the atrocities perpetrated by the Nazis, and aware of the dangers of his double role. Reverzy testified that Fuchs did not participate in the interrogations and arrests, and that his only role was to interpret and mediate between the prisoners and their families. There were also letters of acknowledgment from other prisoners, such as Aurélie Leydevant, who declared that she was released from Pax prison thanks to Fuchs, and some camp inmates who were sent to the infirmary where they were taken care of by Fuchs. All these letters highlight the politeness with which they were treated, the risks that Fuchs took when helping them, and the devotion he showed towards Gestapo detainees and camp prisoners (particularly French and Belgian inmates).

However, in order to continue working as triple-agent and maintain his humanitarian role, Fuchs still had to perform his interpreting duties for the Germans. In fact, he and Barbie became well acquainted "as so often happened in relationships between wartime employers and their interpreters" (Ott, 2009, p. 72), and Fuchs's clear inclination towards members of the Resistance allowed him to influence Barbie's decisions regarding his soldiers: "chaque fois qu'un Sturmmann (homme de troupe dans la SS) avait un manquement (...) je faisais un rapport et le fautif était envoyé sur le front ${ }^{14 ”}$ (Fuchs, p. 111). He was predisposed against the Germans just as he was compassionate toward their enemies.

His decisions had also serious and unforeseen consequences for other parties. For example, Fuchs was involved in the orchestration of an escape attempt for one of the members of the Resistance, Raymond Aubrac. However, during the escape, the driver was killed, and in the aftermath the examining magistrate for whom Fuchs worked in Annemasse was sent to the Russian Front. This came about after Fuchs showed a Nazi officer letters of release supposedly signed by the magistrate, when, in actual fact, the letters had been faked by the interpreter. In another instance, two women who had sent a letter informing on members of the Resistance were killed after Fuchs declared that

\footnotetext{
${ }^{12}$ You have been summoned to appear tomorrow morning at 6 am at Gestapo headquarters. And I added: and I hope you will be already far away from here by then.

13 Abbreviation of "Schutzstaffel" ("Protective Echelon"). The SS was a paramilitary organisation created by Adolf Hitler in 1925. They were considered an elite corps; the political soldiers of the Nazi Party.

${ }^{14}$ Every time a Sturmmann (SS soldier) was found negligent (...) I drafted a report and the culprit was sent to the front.
} 
he had found nothing in the house of the accused and that the pair were wasting the Gestapo's time. Finally, Jewish Opera singer Josef Schmid was confined and died of lung congestion in a migrant reunification camp after Fuchs, wrongly convinced that Schmid was a secret agent, denounced him to Swiss intelligence.

\section{The role of emotions and ideology in the interpreter's agency}

In Fuchs's story we may observe some similarities with the interpreter described by Guo (2015). Contrary to the prescribed neutrality that permeates interpreting codes of ethics, Fuchs participated in the political relationships created between the different parties and manifestly sided with one of them - making use both of his position as an interpreter and of the close relationship he maintained with Barbie, in order to accomplish his mission as a double agent. Interpreting was more than a simple professional activity for Fuchs: it was a smokescreen to hide his intelligence activities, and afforded him access to high-level Nazi officers and classified documents. It is worth noting that his actions, as he narrates them in his memoirs, were influenced by his negative emotions against the occupiers and by his desire to help the cause in which he believed.

There is a lack of integration of the disparate experiences that make up his biography; a confrontation between habitus and field which led to internal conflict and powerful emotions. Similar to the stories described by Reay (2015), Fuchs had to negotiate the Gestapo and the Resistance cultures, characterised by a clash of interests and ideological principles, and his memoirs "speak to the difficulty of managing movement across two different and at times opposing fields” (p. 13). His actions were influenced by this divided habitus that explains his modus operandi and the changes in his individual conduct. The experiences that stemmed from inhabiting pathologized spaces within the field resulted in emotions of indignation, resentment and fear. However, he was also subject to positive emotions - empathy and hope - as a result of helping those he considered powerless.

Fuchs's anger stemmed from his perception that the Germans' behaviour was the result of an intrinsic and immutable aspect of their nature. However, I argue that indignation is the most powerful emotion present throughout his memoirs. He perceives the occupying forces to have unjustly harmed the French. Another related emotion is resentment towards the Nazis - the German Nazis, who should not hold political superiority, and their sympathisers amongst the French. In fact, Fuchs felt a profound repugnance for those ordinary French citizens who served the interests of the Germans. The delegitimization and dehumanisation of the enemy was made possible through the emotions of hatred and anger, through the feeling that the enemy's behaviour could not be changed, by considering the outgroup's character to be intrinsically negative, and by refusing to accept any positive knowledge about the opponent. In addition, the perception of fear as a future-oriented emotion the anticipation that something might happen depending on present actions combined with a sense of excitement from doing something dangerous and the thrill of duplicity, as seen in the case of other double agents such as Jean Laborde (see Ott, 2009), are also found in Fuchs's account of his double role.

On the other hand, as a consequence of his helping those he considered as weak or as allies, other positive emotions also emerged for Fuchs, particularly compassion, empathy and hope. In Rosler, Cohen-Chen and Halperin's (2017) study, empathy may lead an individual to relieve the suffering of the out-group, and hope leads him to search for new solutions to conflict. It allows him to imagine a more positive future, and find solutions to disputes by believing in a future that is different to the past and present realities; it is this idea that encourages him to take risks (Halperin, 2014). 
In the case of Fuchs, all these emotions are filtered by the ideology of the Resistance and the eagerness to help his anti-German connections. Fuchs constitutes, in terms of Costalli and Ruggeri (2015) a "follower": that is, a person who joins an ideological network created by the political entrepreneurs, the leaders of the Resistance. He felt increasingly detached or emotionally disconnected from the status quo, followed the ideological motivations dictated by the Resistance and employed these actions, which resulted in an anchoring and ownership of the ideology and his mobilisation against the Nazi Germans. He became a double agent because he was predisposed to risk, something that we have seen from his early involvement in activism: he took on the risks of the role because he believed it was feasible and that some tangible support existed. Increasing indignation and resentment towards the Germans, and empathy towards enemies of the Nazis, combined with a feeling of hope, are ubiquitous qualities throughout his narrative, and constitute an important element when analysing his agency as interpreter. This active involvement through his position as an interpreter had an impact on Fuchs's stance when relating his experiences.

\section{Conclusions}

Wars are inherently psychological conflicts because they have an impact on societies' beliefs about and reactions towards conflict-related scenarios and events. These conflicts have a devastating effect on populations and on the international community at large. Civilians who live in societies ravaged by wars suffer severe negative experiences and are surrounded by negative messages that affect their appraisal of the conflict and give rise to negative emotions. These emotional underpinnings are underlying factors that explain a certain ideology and a specific reaction to the stimulus underlying the emotion. Societies in conflict develop certain beliefs that contribute to their sense of uniqueness and become an integral part of the narratives surrounding them. These beliefs in turn lead to the evocation of emotions, and constitute cues for how a societies' members interpret the information they receive.

This article focuses on the complexities of the interpreter's agency in a historical period and a space - the German occupation of France - characterised by the coexistence of opposite ideologies and by, as Otto (2009) puts it, ambiguity, complexity, self-interest, opportunism, choice and chance. Delving into the lived experience of Gottlieb Fuchs shows, on the one hand, how the boundaries between the interpreter and the individual embedded in the ideological narratives of the time were blurred as he tried to use his position as an interpreter to pursue ideological precepts and, on the other hand, how his actions went beyond an evaluation of economic or political benefits and were influenced by this ideology. This increasingly deep-seated ideology had an influence on the emotions Fuchs experienced in the interpersonal communication he conducted in conformity with different collective groups. These emotions, in turn, shaped his habitus. Although it is true that scholars in the field of translation studies have long recognised the research possibilities that Bourdieu's conceptual framework entails, other authors, such as Reay (2005, 2014), have highlighted how emotions are overlooked in the Bourdieusian definition of the key concept of habitus and its relation to the notion of field, which constitute useful notions with which to examine the interpreter's agency.

The case of Gottlieb Fuchs strengthens and elucidates these mainstream themes in studies of the role of the interpreter in wartime. Examination of Fuchs's memoirs shows that his actions were significantly affected by emotions, and illustrates the implications of siding with one of the parties to a conflict on the basis of ideological principles. The decisions made by Fuchs when using his 
position on one person's behalf could equally affect another's experiences and fates: he could not always foresee the implications of attaining certain goals or the impact his choices would have on other people. As Fuchs's case shows, there are always unforeseen repercussions that stem from the interpreter's choices and are beyond his control, and his reactions when narrating these unexpected consequences with hindsight are also filtered through emotions.

The role of ideology and emotions in the interpreter's agency is an added dimension to a recurrent and principal theme found in interpreting studies: the neutrality of interpreters in war scenarios. Through being immersed in conflict and exposed to war narratives, these individuals may be led to adopt an ideology that triggers emotions, and these affective responses may in turn have an impact on their actions. More research is needed to understand and evaluate the influence of the affective on the interpreter's agency in wartime.

\section{References}

Aschenberg, H. (2016). Linguistic terror in Nazi concentration camps: Lucien and Gilbert. Portrait of two "interpreters". In M. Wolf (Ed.), Interpreting in Nazi concentration camps (pp. 63-78). New York: Bloomsbury.

Baker, M. (2006). Translation and conflict: A narrative account. London: Routledge.

Bauman, Z. (1988). Sociology after the Holocaust. The British Journal of Sociology, 39(4), 469-77.

Bourdieu, P. (2000). Pascalian meditations. Cambridge: Polity Press.

Calvino, I. (1964). Il sentiero dei nidi di Ragno [The path to the nest of spiders]. Torino: Einauldi.

Costalli, S., \& Ruggeri, A. (2015). Indignation, ideologies and armed mobilisation: Civil war in Italy, 1943-45. International Security, 40(2), 119-157.

Delgado, C., \& Kherbiche, L. (2018). Without fear or favour? The positionality of ICRC and UNHCR interpreters in the humanitarian field. Target, 30(3) 408-429.

Fuchs, G. (1973). "Le Renard”. 30 ans après l'interprète de Barbie parle [The Fox. 30 years later Barbie's interpreter speaks out]. Paris: Albin Michel.

Germain, M. (1992). Le sang de la barbarie: chronique de la Haute-Savoie au temps de l'occupation allemande, septembre 1943-26 mars 1944 [The blood of barbarism. A chronicle of Haute-Savoie at the time of the German occupation, September 1943-26 March 1944]. France: La Fontaine de Siloé.

Guo, T. (2015). Interpreting for the enemy: Chinese interpreters in the Second SinoJapanese War (1931-1945). Translation Studies, 8(1), 1-15.

Gutiérrez Sanín, F., \& Wood, E. J. (2014). Ideology in civil war: Instrumental adoption and beyond. Journal of Peace Research, 51(2), 213-226.

Halperin, E. (2011). Emotional barriers to peace: Emotions and public opinion of Jewish Israelis about the peace process in the Middle East. Peace and Conflict, 17, 22-45.

Halperin, E. (2014). Emotion, emotion regulation, and conflict resolution. Emotion Review, 6(1), 68-76.

Hilgers, M., \& Mangez, E. (2014) (Eds.). Bourdieu's theory of social fields: Concepts and applications. London: Routledge.

Inguilleri, M. (2005a). The sociology of Bourdieu and the construction of the "object" in translation and interpreting studies". The Translator, 11(2), 125-145.

Inghilleri, M. (2005b). Mediating zones of uncertainty: Interpreter agency, the interpreting habitus and political asylum adjudication. The Translator, 11(1), 6985.

Kuhiwczak, P. (2016). Interpreting under pressure: From collaboration to resistance. In M. Wolf (Ed.), Interpreting in Nazi concentration camps (pp. 219-226). New York: Bloomsbury.

Ott, S. (2009). Duplicity, indulgence and ambiguity in Franco-German Relations, 19401946. History and Anthropology, 20(1), 57-77.

Pearlman, W. (2013). Emotions and the microfoundations of the Arab uprisings. Perspectives on Politics, 11(2), 387-409.

Reay, D. (2004). 'It's all becoming a habitus': Beyond the habitual use of habitus in educational research. British Journal of Sociology of Education, 25, 431-444. 
Reay, D. (2015). Habitus and the psychosocial: Bourdieu with feelings. Cambridge Journal of Education, 45(1), 9-23.

Rosler, N., Cohen-Chen, S., \& Halperin, E. (2017). The distinctive effects of empathy and hope in intractable conflicts. Journal of Conflict Resolution, 61(1), 114-139.

Rousso, H. (n.d.). From Klaus Barbie to Klaus Altmann. Chemins de mémoire. Retrieved from http://www.cheminsdememoire.gouv.fr/en/klaus-barbie-klausaltmann

Sabucedo, J. M., Durán, M., Alzate, M., \& Barreto, I. (2010). Emotions, ideology and collective political action. Universitas Psychologica, 10(1), 27-34.

Suleiman, S.R. (2002). Memory and moral judgment in documentary film: On Marcel Ophuls's “Hotel Terminus: The life and times of Klaus Barbie”. Critical Inquiry, 28(2), 509-541.

Wolf, M. (2016). Interpreting in Nazi concentration camps. New York: Bloomsbury. Wacquant, L.J.D. (1989). Towards a reflexive sociology: A workshop with Pierre Bourdieu. Sociological Theory, 7(1), 23-63. 